\title{
REVIEW
}

\section{Reactive arthritis or chronic infectious arthritis?}

\author{
J Sibilia, F-X Limbach
}

Ann Rheum Dis 2002;61:580-587

Microbes reach the synovial cavity either directly during bacteraemia or by transport within lymphoid cells or monocytes. This may stimulate the immune system excessively, triggering arthritis. Some forms of $\operatorname{ReA}$ correspond to slow infectious arthritis due to the persistence of microbes and some to an infection triggered arthritis linked to an extra-articular site of infection.

See end of article for authors' affiliations ...................

Correspondence to: Professor J Sibilia, Service de Rhumatologie, Hôpital de Hautepierre, 1 avenue Molière, 67098 Strasbourg, Cedex, France; jean.sibilia@wanadoo.fr

Accepted 4 March 2002
$\mathrm{R}$ eactive arthritis (ReA) was first described in 1916 during the first world war by Fiessinger and Leroy in France and Reiter in Germany. It was, however, only in 1969 that a Scandinavian team rationalised the concept of ReA by defining it as a transient non-purulent (reactive) arthritis appearing in the weeks following a digestive infection. ${ }^{1}$ Actually, this notion of exclusively aseptic ReA has been repeatedly contradicted by different observations. ${ }^{2-5}$

\section{MICROBIOLOGICAL HISTORY OF REACTIVE ARTHRITIS: FROM MICROSCOPY TO MOLECULAR BIOLOGY}

A study of the microbiological history of ReA is instructive as it illustrates well the influence of technological progress and, in particular, the impact of molecular biology on the evolution of such concepts.

- As early as the 1970s, the first studies disclosed microscopic intracellular inclusions in synovial tissues which could correspond to Chlamydia trachomatis, the principal arthritogenic microbe involved in ReA. ${ }^{6}$ Confirmation of this work was, however, hindered for many years by the fact that most of these bacteria are very difficult or almost impossible to cultivate from synovial samples. ${ }^{7-11}$

- Since the beginning of the 1990s, the explosive development of new molecular biology techniques has led to the detection (by polymerase chain reaction methods) of small quantities of $C$ trachomatis DNA in the articular cavity. ${ }^{12-16}$ These first results immediately raised a large number of questions. Did they indicate the presence of viable bacteria in the joint, or were these simply genomic vestiges of bacteria passively transported into the joint by macrophages? The reply was provided by the discovery of messenger and ribosomal RNA of $C$ trachomatis using a reverse transcriptasepolymerase chain reaction (RT-PCR) method. ${ }^{17}$ The presence of these nucleic acids, which have a very short half life in tissues (some minutes), implies the occurrence of transcription and hence active multiplication of the bacteria. These findings thus suggest that microbes can survive in small numbers in the articular cavity in certain forms of ReA (table 1).

- The phenomenon has grown since 1995 with discovery of DNA of most other classical arthritogenic agents in synovial samples from patients with ReA. ${ }^{18-21}$ One must nevertheless take a fairly critical point of view because although the results are convincing for $C$ trachomatis, they are much less so for enterobacteria. It is true that DNA of Yersinia, Shigella, or Campylobacter has been identified in some studies, but these are few and include very few patients. ${ }^{18} 192122$ Thus, Ekman et al identified DNA of Salmonella in synovial samples, ${ }^{23}$ but could not repeat their results. This might have been owing to technical artefacts, which lead to false positives, or to a very small amount of bacterial DNA in the synovium. Despite these reservations, the list of arthritogenic agents continues to grow from year to year, even if for many of them there is no confirmation of their intrasynovial persistence (table 2). ${ }^{18}{ }^{19-33}$ Chlamydia pneumoniae and Borrelia burgdorferi, for instance, have been associated with cases of monarthritis or oligoarthritis comparable with those seen in ReA. ${ }^{34-37}$ In this context, it is interesting to return to the case described by Reiter in 1916 and his publication entitled "Über eine bisher unerkannte Spirochäteninfektion (Spirochaetosis arthritica)". ${ }^{38}$

One might wonder, in view of the high prevalence of $B$ burgdorferi infections in Central Europe, whether this spirochaete rheumatism was not one of the first reports of Lyme arthritis? Identical observations have been made in other situations quite closely related to ReA. Propionibacterium acnes, a microbe implicated in inflammatory outbreaks of acne, was recently identified in articular samples from SAPHO patients, suggesting an infectious origin of this syndrome often regarded as a form of spondyloarthropathy. ${ }^{39}$ Mycobacterium bovis, used in BCG (Bacille Calmette-Guérin) treatment, is known to cause, presumably aseptic, oligoarthritis and polyarthritis, ${ }^{40}{ }^{41}$ but we have also detected bacterial DNA in synovial fluid from patients with arthropathy triggered by intravesical injection of $\mathrm{BCG}^{42}$ In other situations, the

Abbreviations: IFN, interferon; IL, interleukin; LFA, leucocyte function associated antigen; LPS, lipopolysaccharide; MOMP, major outer membrane protein; Osp, outer surface protein; ReA, reactive arthritis; RT-PCR, reverse transcriptase-polymerase chain reaction; TNF tumour necrosis factor 
Table 1 The principal detectable microbes in reactive arthritis and undifferentiated arthritis: analysis of the different methods of identification

\begin{tabular}{lllll}
\hline & Antigens & DNA & RNA & Culture \\
\hline C trachomatis & + & + & + & $+/-$ \\
$Y$ enterocolitica & + & $+{ }^{* 21}$ & ND & - \\
$Y$ pseudotuberculosis & + & - & $+\dagger^{22}$ & - \\
S flexneri and sonnei & + & $+{ }^{* 18}$ & ND & - \\
S typhimurium and enteritidis & + & $+{ }^{* 108}$ & ND & - \\
C jejuni & - & $+{ }^{* 18}$ & ND & - \\
U urealyticum & + & + & - & + \\
C pneumoniae & + & + & + & - \\
B burgdorferi & + & + & ND & + \\
$T$ whippelii & + & + & ND & + \\
\hline
\end{tabular}

ND, not done

* The detection of nucleic acid of enterobacteria in the synovium is subject to caution for reasons related to the different techniques employed and the very small numbers of patients studied; †RNA has only been detected in one case.

Table 2 List of the "classical" and "new" arthritogenic agents implicated in reactive arthritis

\begin{tabular}{|c|c|}
\hline "Classical" candidates & "New" candidates \\
\hline $\begin{array}{l}\text { - Chlamydia trachomatis } \\
\text { - Ureaplasma urealyticum } \\
\text { - Yersinia enterocolitica and } \\
\text { pseudotuberculosis } \\
\text { - Shigella flexneri and sonnei } \\
\text { - Salmonella typhimurium, enteritidis } \\
\text { - and others }\end{array}$ & $\begin{array}{l}\text { - Chlamydia pneumoniae } \\
\text { - Mycoplasma hominis and } \\
\text { - Neisseria gonorrhoeae } \\
\text { - Borrelia burgdorferi } \\
\text { - Clostridium difficile } \\
\text { - B-Haemolytic streptococci } \\
\text { - Propionibacterium acnes } \\
\text { - Escherichia coli } \\
\text { - Helicobacter pylori } \\
\text { - Brucella abortus } \\
\text { - Calmette - Guerin Bacillus } \\
\text { - Leptospira } \\
\text { - Bartonella } \\
\text { - Trophyrema whippelii } \\
\text { - Gardnerella vaginalis } \\
\text { - Giardia lamblia }\end{array}$ \\
\hline
\end{tabular}

discovery of inflammatory articular manifestations, sometimes of unexplained recurrent arthritis following documented infection, suggests the possibility of reactive arthritis "in the wide sense of the term". ${ }^{27}{ }^{43} 44$ However, in the majority of these cases, the proof is not tangible, although sufficient for one to keep in mind the hypothesis.

Recently, in 1998, new observations came to light which complicated the picture: the joint is not a sterile medium, as shown by the discovery of DNA of $C$ trachomatis (by PCR) in synovial samples from healthy volunteers and patients with osteoarthritis (in respectively $9 \%$ and $20 \%$ of cases).$^{45}$ In this study, only PCR amplifications using primers hybridising with 16S RNA or plasmid genes were positive, while attempts to amplify the major outer membrane protein (MOMP) gene were always negative. This suggests, assuming these results to be pertinent, that the bacteria persist in a "particular" form. It should nevertheless be noted that the variability of the PCR results can equally be explained by differences in sensitivity related to the amplification target. Similarly, use of the "generic" technique known as "universal" bacterial gene amplification has allowed the detection of a certain number of unexpected intrasynovial microbes, the pathogenic significance of which remains to be confirmed, because this type of method carries the risk of amplifying a commensal bacterium or contaminant gene of no particular importance. ${ }^{46}$
Recent original work has confirmed the simultaneous presence of RNA of numerous bacterial species in synovial samples from patients with rheumatoid arthritis, unexplained arthritis, and osteoarthritis, but not in samples taken during meniscectomy from presumably healthy subjects. ${ }^{47}$ In this study employing RT-PCR, respectively 92 and 50 different bacterial species were identified by sequencing in the synovial fluid of rheumatoid arthritis and osteoarthritis. Only six species (Corynebacterium, Escherichia coli, Streptococcus, Pseudomonas, Leptospira, and Methylobacterium) were detected exclusively in rheumatoid arthritis, although without proof of this being an argument in favour of their pathogenic role. These astounding results, apparently obtained by reliable methods, demonstrate that the synovium is not a sterile structure, but more probably an interfacial zone which can be colonised by bacteria originating from the environment and the endogenous flora

"The synovium is not sterile but can be colonised by bacteria from the environment"

Recently, a description was given of arthritogenic microbes detectable in synovial samples not only in cases of presumably ReA but also in other forms of inflammatory rheumatism..$^{12}{ }^{48-50}$ In fact, $C$ trachomatis and pneumoniae are present in the synovial fluid of patients with rheumatoid polyarthritis in respectively $30 \%$ and $15 \%$ of cases $^{51}$; identical observations have been reported for Mycoplasma pneumoniae and fermentans. ${ }^{48}{ }^{49}$ Sometimes several microbes may be found together in the same joint, as suggested by the RT-PCR study described above. ${ }^{47}$ This unusual association was observed for $C$ trachomatis and pneumoniae and for $C$ trachomatis and $B$ burgdorferi in synovial samples from patients with spondyloarthropathy, unexplained arthritis, and even rheumatoid arthritis. ${ }^{51}$ One should nevertheless maintain a critical attitude until these results have been confirmed by other studies. Thus, one report published only in abstract form suggests that the presence of intrasynovial bacterial DNA might after all be an exceptional phenomenon..$^{52}$ In this work, a search by PCR analysis for the bacterial $16 \mathrm{~S}$ and $23 \mathrm{~S}$ ribosomal RNA genes proved negative in the synovium of 81 patients (42 rheumatoid arthritis, 8 other cases of inflammatory rheumatism, 31 osteoarthritis) when using drastic conditions of sterility.

\section{THE PATHOGENIC MECHANISMS OF REACTIVE ARTHRITIS}

The most original microbiological observations described in the previous section raise a number of questions which require an answer to help to understand the pathogenesis of reactive arthritis.

\section{How do these bacteria persist in the articular cavity and} escape from the immune system of the host?

Role of antigenic modulation

Several recent studies have shown that $C$ trachomatis can survive in a particular form whereby it down regulates the expression of membrane antigens (MOMP), while continuing to synthesise immunomodulatory proteins like heat shock proteins..$^{53}$ It has further been shown that these modifications can be induced in vitro by prolonged antibiotic treatment (ciprofloxacin) ${ }^{54}$ which might have important practical implications for future therapeutic strategies.

B burgdorferi can likewise modulate its expression of surface antigens. On entering the host, this bacterium in fact down regulates expression of the principal membrane outer surface protein A (OspA) and expresses larger quantities of another membrane protein OspC..$^{55}$ Such antigenic modifications may permit these bacteria to escape from the immune system of the host. 
Role of intracellular localisation of the bacterium As pointed out by Zinkernagel, numerous circumstances exist in which micro-organisms (especially viruses) escape from the immune system by persisting in non-lymphoid cells (papillomavirus in keratinocytes, Epstein-Barr virus in epithelial cells).$^{56}$ Similarly, certain arthritogenic bacteria can enter and persist in the synoviocytes (or other cells such as endothelial cells), sometimes despite use of antibiotics, as has been shown for $C$ trachomatis and B burgdorferi. ${ }^{77-62}$

\section{"Arthritogenic bacteria can persist in synoviocytes despite antibiotic treatment"}

The situation is less clear in the case of enterobacteria and differs according to the microbe. Yersinia and Salmonella can persistently infect the mucosa of the intestine and the digestive ganglions but not the synovium. These microbes are also present in monocytes, which serve perhaps as a reservoir but above all as "transporters" from extra-articular sites into the joint. ${ }^{63-65}$ Shigella, conversely, only infects digestive epithelial cells and cannot survive in monocytes and its mechanisms of persistence and transport are less well known.

\section{Role of molecular mimicry}

Certain bacteria have constituents which display strong homology with proteins of the host (YopH of $Y$ pseudotuberculosis and CD45, $M$ fermentans and CD4). This molecular mimicry can give rise to a tolerance to some microbes, which may thus escape from the immune system of the host. One recently described example is the case of Lyme borreliosis. It has been shown that a dominant epitope of OspA of $B$ burgdorferi (usually presented by HLA-DRB1*04 01) has close sequence homology with leucocyte function associated antigen-1 (LFA-1), which is a $\beta 2$-integrin expressed at the surface of lymphocytes, polynuclear granulocytes, and monocytes. ${ }^{66}$ As a result, OspA can bind to intracellular adhesion molecule-1 (ICAM-1), a ligand of LFA-1 expressed by synoviocytes, enabling the bacterium to persist in the synovium. On the other hand, the mimicry may also be differently interpreted by the host because the homology between this bacterial constituent and an antigen of the articular cavity can induce an "autoimmune" synovitis, as will be discussed later.

Role of interactions with the immunogenetic characteristics of the host

To resolve an infection, especially with intracellular bacteria, cytokines such as interferon $\gamma$ (IFN $\gamma$ ) produced by T cells play a major part. ${ }^{67}$ It has been shown that in ReA the antibacterial Thl cytokine response (production of IFN $\gamma$, interleukin 2 (IL2) and IL12) is impaired in favour of a Th2 response (IL4 and IL10). ${ }^{68-73}$ Thus, in the absence of a "good" antibacterial reaction, the microbes can survive. Little is known about the pathogenesis of this Thl/Th2 imbalance, but it is likely that genetic factors of the host are causally involved. Among these factors, the polymorphism of cytokine genes is probably implied. For instance, in Finnish patients, the microsatellites IL10.G10 and IL10.G12 from the promoter region of the IL10 gene seem to be protective against the development of ReA. ${ }^{74}$ In a German study, it has been demonstrated that the level of tumour necrosis factor $\alpha(\mathrm{TNF} \alpha)$ secretion by T cells at ReA onset is inversely proportional to the disease duration and severity. ${ }^{75}$ However, ReA cannot be explained merely by cytokine production or polymorphism and other susceptibility factors certainly play a part. One of them is that arthritogenic bacteria like Yersinia or Salmonella can modulate HLA-B27 (modification of the messenger RNA splicing, peptide modification) and, possibly, the lymphocyte response. ${ }^{76}$ These interferences may facilitate the persistence of the bacteria within cells or tissues.
How can these bacteria, which seem to escape from the immune system of the host, cause arthritis?

An analysis of the microbiological and immunological data suggests the existence of two forms of reactive arthritis.

Reactive arthritis of the type chronic infectious arthritis Certain forms of ReA may represent authentic chronic infectious arthritis caused by slow growing organisms which are very difficult to cultivate and hence impossible to identify by the usual microbiological methods. In the light of current knowledge, this hypothesis would appear to hold for Chlamydia, Mycoplasma, and Borrelia, although not for enterobacteria. Such microbes enter the articular cavity during bacteraemia or within monocytes ${ }^{77} 78$ and can survive in small numbers in a "vegetative" state, probably with intermittent periods of replication triggered by still unknown phenomena. ${ }^{753578}$ This has been clearly demonstrated for $C$ trachomatis, which persists in the form of "atypical" reticulated bodies. ${ }^{79} 80$

These microbes have an attenuated virulence, unlike those responsible for septic arthritis. Such forms of ReA are thus related to a "slow" intrasynovial infection, a condition also called "slow infectious arthritis" or "infection reactive arthritis". ${ }^{81}$ Similarly, it is by invoking the same mechanisms that one explains today the arthritis of Whipple's disease, whereas for many years it was not possible to identify or cultivate this slow growing organism. ${ }^{29} 30$

\section{Reactive arthritis of the type infection triggered aseptic} arthritis

Some forms of ReA are probably aseptic and if so it is the persistence of bacterial antigens (lipopolysaccharides, heat shock proteins) which may explain the appearance of an inflammatory reaction in the synovium. This hypothesis applies above all to enterobacteria (Yersinia, Salmonella ...), microbes not found in the joint except possibly in authentic (but rare) cases of acute septic arthritis. ${ }^{82-86}$ In chronic forms, it is unlikely that viable and active bacteria persist in the synovium, although it has occasionally been possible to detect bacterial DNA ${ }^{18} 1921-23$ and even recently intrasynovial RNA in a case of ReA caused by Yersinia pseudotuberculosis. ${ }^{22}$ Conversely, it is likely that these bacteria survive at an extra-articular site, in particular in the mucosal membranes of the digestive system and/or the lymphatic ganglions, and are carried to the joint by monocytes, probably in recurrent fashion..$^{63-65}$ In support of this theory, there is some evidence indicating that a preferential connection exists between gut and joints. It has been observed that mucosal leucocytes collected from patients with an inflammatory bowel disease can bind well to synovial vessels. ${ }^{87}$ This homing implies many receptors and their ligands, which differ according to the leucocyte subset, and mononuclear cells from peripheral blood do not share the binding characteristics of gut derived cells. Although these results only concern inflammatory bowel diseases, the concept can probably be applied to enteric ReA. After the homing, the bacterial antigens can subsequently persist sometimes for a long time in the synovium, in certain cases in the form of bacterial "ghosts" without nucleic acid. ${ }^{84}{ }^{85}$ This type of arthritis, triggered by bacterial antigens originating from an extraarticular site in the absence of any viable intra-articular microbe, may be called "infection triggered reactive arthritis".

\section{What are the bacterial factors and the immunogenetic factors of the host which are important to explain the appearance of arthritis?}

Although the above description of the two forms of reactive arthritis gives a fairly simple picture, it is possible that the future will reveal a more "heterogeneous" reality. In any case, the appearance of arthritis is a consequence of the encounter between an arthritogenic bacterium and a predisposed host. Thus the key to the mystery of ReA will undoubtedly lie in a 
Table 3 Arthritogenic microbes implicated in reactive arthritis: role of HLA-B27

\begin{tabular}{ll}
$\begin{array}{l}\text { Arthritogenic bacteria } \\
\text { dependent on HLA-B27: the } \\
\text { "classical" candidates }\end{array}$ & $\begin{array}{l}\text { Arthritogenic bacteria } \\
\text { independent of HLA-B27: the } \\
\text { "new" candidates }\end{array}$ \\
\hline - Chlamydia trachomatis & - Ureaplasma urealyticum \\
- Yersinia enterocolitica and & - Neisseria gonorrhoea \\
pseudotuberculosis & - B-Haemolytic streptococci \\
- Salmonella typhimurium, & - Borrelia burgdorferi \\
enteritidis and others & - Brucella abortus and mellitensis \\
- Shigella flexneri and sonnei & \\
- Campylobacter jejuni & \\
- Clostridium difficile & \\
\hline
\end{tabular}

detailed study of these host-bacterium interactions, of which we already know some of the subtleties.

- All bacteria do not have the same arthritogenic potential. As an example, certain strains of Shigella flexneri contain a plasmid with a gene coding for a peptide sequence homologous to the HLA-B27 molecule, which could confer particular arthritogenic properties. ${ }^{88}$ The arthritogenic strains of Yersinia also possess plasmid and chromosome virulence factors which can modulate the processes of cellular adhesion and invasion. ${ }^{89}$ Other examples may exist, like for instance Lyme arthritis in Europe, which would seem to be preferentially related to $B$ burgdorferi sensu stricto, ${ }^{90}$ although the virulence factors of this species are not yet known.

- The immunogenetic characteristics of the host likewise have an important role, especially HLA-B27, but not necessarily as an antigen presenting molecule because studies based on this mechanism remain inconclusive. Indeed, it has been shown that the adhesion molecules of certain bacteria (Yersinia, Salmonella) use HLA-B27 as a ligand to attach to cells of the synovial environment. ${ }^{91}{ }^{92}$ Moreover, in some genetically predisposed subjects, HLA-B27 appears to lack the ability to eliminate infected macrophages normally, thus facilitating the intra-articular persistence of the microbe (Salmonella). ${ }^{93-95}$ Recently, a new attractive hypothesis was proposed by Colbert's group about the role of HLAB27 in ReA. ${ }^{96}$ This team has shown that during the antigen processing and assembly pathway into the endoplasmic reticulum, HLA-B27 has a tendency to misfold even without any $\beta 2 \mathrm{~m}$ or peptide deficiency. This misfolding implicates the $\mathrm{B}$ pocket of the molecule and may, at least partially, explain the link between HLA-B27 and arthrogenicity. Misfolding can lead to a stress response which could increase the production of proinflammatory cytokines by an activation of NF-kB. Moreover, accumulation of HLA-B27 heavy chains might induce the formation of abnormal homodimers at the cell surface and in this way activate the immune system. ${ }^{97}$ However, some types of reactive arthritis are not linked to HLA-B27 but probably to other immunogenetic factors ${ }^{8898}$ and one can distinguish at present the forms dependent on and independent of HLA-B27 (table 3).

\section{What are the mechanisms leading to the development of synovitis during reactive arthritis?}

The mechanisms inducing an inflammatory reaction of the synovium are basically the same in the two types of reactive arthritis.

Bacterial lipopolysaccharides (LPS): mechanism of action Bacterial products, and in particular LPS, are powerful macrophagic stimulators which can trigger the synthesis of proinflammatory cytokines (TNF $\alpha$, ILl, IL6) through CD14Tll-like receptor activation. This mechanism plays a part in ReA induced by Chlamydia and in the forms involving enterobacteria. $^{82} 99100$

\section{Bacterial antigens}

Bacterial antigens, whether produced by a viable intrasynovial bacterium or brought into the articular cavity by monocytes, have an immunostimulatory action. These antigens can most likely persist in the joint either "stuck" to the extracellular matrix or within antigen presenting cells and by the various mechanisms described below can trigger a lymphocyte reaction potentially responsible for arthritis. ${ }^{100-102}$ It remains to be explained why this antibacterial response can in certain subjects exceed its physiological protective role and induce synovitis:

- Either the bacterial antigens are simple polyclonal lymphocyte activators which can stimulate multiple $\mathrm{B}$ or $\mathrm{T}$ clones in a non-selective manner, as has been demonstrated for Mycoplasma

- Or some antigens may behave as superantigens which can stimulate whole families of T lymphocytes characterised by a particular T receptor, as has been demonstrated for Yersinia and Mycoplasma

- Or some bacterial antigens display close homology with a "self" antigen (molecular mimicry), which as already mentioned can induce a form of tolerance enabling the bacterium to avoid elimination. However, this mimicry can likewise trigger veritable "autoimmune" intra-articular inflammatory reactions in predisposed subjects. There are many known examples of microbial homology: some epitopes of Shigella and Ureaplasma display strong homology with HLA-B27, $M$ fermentans has an epitope sharing sequence homology with CD4, and one of the best examples is probably the recently discovered sequence homology between OspA and LFA-1 described in a preceding section. This induces in certain subjects a strong intra-articular anti-OspA/LFA-1 lymphocyte response, which could participate in the pathogenesis of Lyme arthritis. ${ }^{66}$ Nevertheless, there are several reasons (modification of the expression of OspA, species diversity of OspA) for thinking that this mechanism is of no major importance, even if it may exist in some chronic forms of the disease.

\section{A new immunostimulator: bacterial DNA}

A new, most attractive hypothesis just put forward recently suggests another candidate immunostimulator. Bacterial DNA, which differs from that of eukaryotes by the presence of more non-methylated CpG motifs, can stimulate intensely monocytes-macrophages. It has been shown that experimental intra-articular injection of bacterial DNA (Escherichia coli, Staphylococcus aureus) or simply of non-methylated CpG motifs is sufficient to trigger arthritis in mice. ${ }^{103-105}$ The hypothesis is that bacterial DNA may be directly responsible for part of the synovial inflammation. This merits further investigations in man, particularly to assess whether the quantity of bacterial DNA required to induce arthritis is comparable with the "inoculum" observed in vitro in reactive arthritis.

\section{SUMMARY: THE IMPORTANCE OF HOST-BACTERIA INTERACTION}

All these points illustrate well the fundamental importance of host-bacterium interactions in the pathogenesis of inflammatory arthropathy. The important facts may be summarised as follows:

- The synovial cavity is not as previously believed a sterile medium, but rather a site accessible to microbes, either directly during recurrent episodes of bacteraemia or by transport within lymphoid cells or monocytes. The prevalence and banality of these infections explains the presence of "bystander" bacterial constituents in synovial samples from patients with osteoarthritis and healthy volunteers. Such intra-articular microbes may then be eliminated, or may trigger a sterile inflammatory reaction, or provoke a 


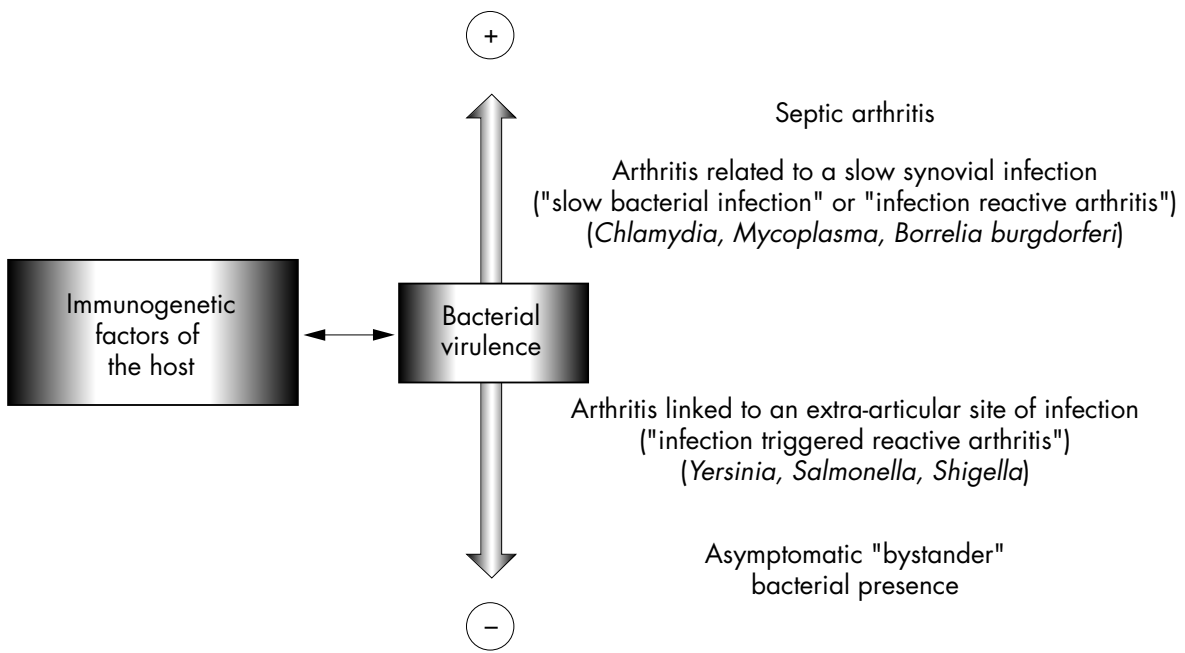

Figure 1 The spectrum of arthritis induced by a bacterial infection. The host-bacterium interactions and, in particular, the bacterial virulence factors lead to different forms of arthritis. In some cases there may be no more than a simple "bystander" bacterial presence in the synovium.

slow synovial infection, depending on the characteristics of the host and different factors controlling the synovial micro-environment (figs 1 and 2 and box 1 ).

- Certain forms of presumably ReA thus sometimes correspond to authentic slow infectious arthritis ( $C$ trachomatis, Mycoplasma, B burgdorferi ...), while "reactive" arthritis of the type infection triggered aseptic arthritis certainly exists. Moreover, there is nothing to indicate that the two mechanisms are exclusive, notably for Borrelia and perhaps for some enterobacteria. At the present stage of our knowledge, one may continue to use the term ReA provided that one distinguishes clearly between the chronic infectious forms related to the intrasynovial persistence of viable microbes and the infection triggered forms linked to an extraarticular site of infection (figs 1 and 2).

\section{CONCLUSION}

The concept of inflammatory rheumatism is probably going to be transformed by study of these slow growing bacteria which have the particular ability of entering the host easily (by binding to mucosal adhesion molecules) and persisting there by "hiding" in certain cells and/or by inducing a specific immune tolerance through molecular mimicry.

It is perhaps these "parasite" bacteria, perfectly adapted to their host, which have been selected in the course of the parallel evolution of the bacterial world and the human species.
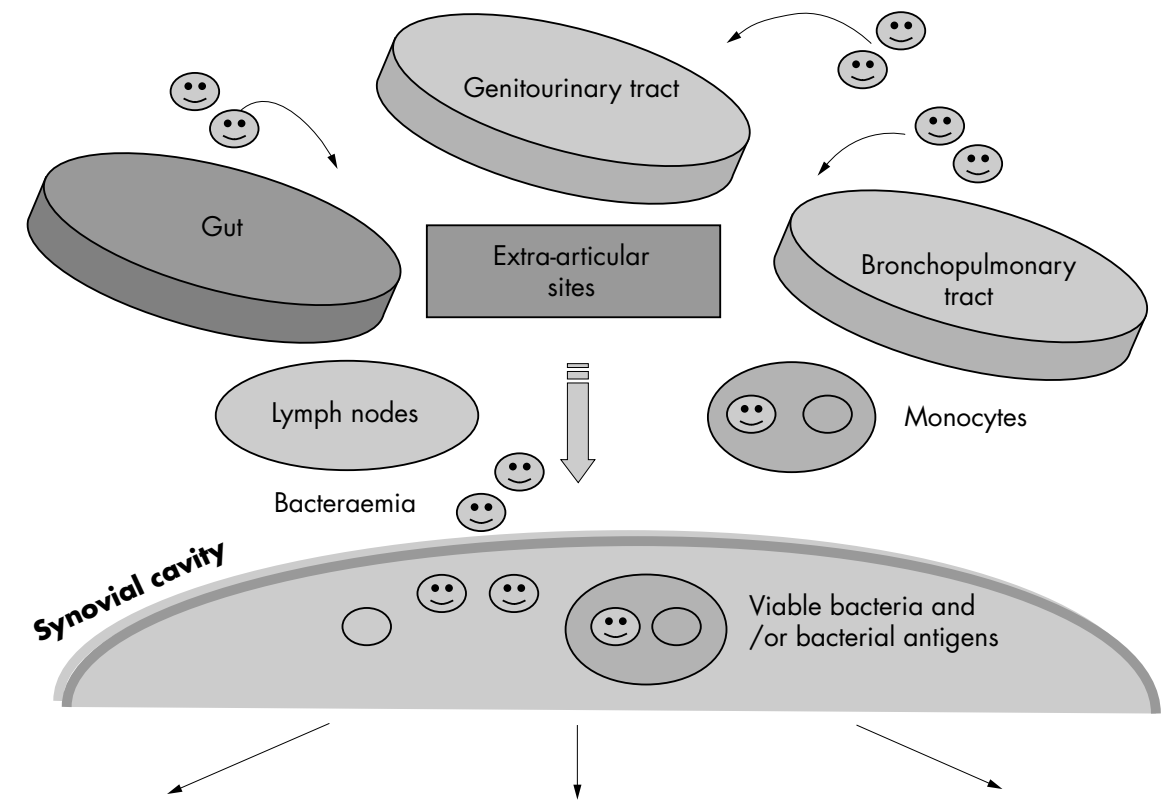

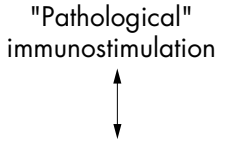

Synovial inflammation $=$ arthritis

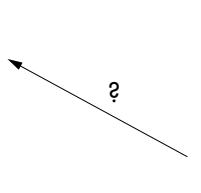

Tolerance

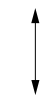

Bystander
"Physiological" antibacterial response

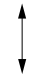

Elimination

Figure 2 Natural history of arthritogenic infections in reactive arthritis. See also Box 1. 
Box 1 Natural history of arthritogenic infections in reactive arthritis

- Arthritogenic microbes gain access to different extraarticular sites, especially mucous membranes ("exchange zone")

- The microbes can persist within these sites and/or disseminate to the articular cavity through recurrent bacteraemia (Chlamydia, Borrelia...) or transported by monocytes (Yersinia, Salmonella,...

- Viable and active microbes (Chlamydia, Micoplasma, ...) or simply bacterial antigenic debris (Yersinia, Salmonella, Shigella...) will reach the synovial membrane

- This "contact" with the synovium can lead to the following sequence of events:

$-\rightarrow$ Elimination of the microbes or their debris by the immune system of an immunocompetent host

- $\rightarrow$ Persistence of viable and active microbes or antigenic debris in "tolerant" hosts, particularly as a result of molecular mimicry

- $\rightarrow$ Excessive stimulation of the immune system of a predisposed host which triggers synovial inflammation (arthritis)

\section{Box 2 Questions looking for an answer}

- How can we put the new methods of gene amplification to practical use for the diagnosis and follow up of such cases of slow infectious arthritis? ${ }^{58} 106107$

- What are the factors which regulate the bacterial virulence or modify the response of the host in these types of arthritis?

- How does one explain the stereotyped clinical and radiological manifestations of some forms of inflammatory rheumatism?

- What are the immediate therapeutic implications likely to evolve from these new discoveries?

This cohabitation results from a subtle equilibrium between the immune response of the host and the virulence of the bacterium. Any modification of one of these factors may lead to the appearance of inflammatory arthropathy of the type ReA and probably also of other forms of peripheral inflammatory rheumatism. However, numerous questions still remain to be answered (box 2)

\section{ACKNOWLEDGEMENTS}

The authors thank Benoît Jaulhac and Yves Piémont from the Institut de Bactériologie de la Faculté de Médecine de Strasbourg (Professor H Monteil).

\section{Authors' affiliations}

J Sibilia, F-X Limbach, Rheumatology Department, University Hospital of Strasbourg, France

\section{REFERENCES}

1 Ahvonen P, Sievers K, Aho K. Arthritis associated with Yersinia enterocolitica infection. Acta Rheum Scand 1969:15:232-53.

2 Aho K, Ahvonen P, Lassus A, Sievers K, Tilikainen A. HLA antigen 27 and reactive arthritis. Lancet 1973; ii: 157

3 Inman RD. Classification criteria for reactive arthritis. J Rheumatol 1999;26:1219-21

4 Kuipers JG, Köhler L, Zeidler H. Reactive or infectious arthritis. Ann Rheum Dis 1999;58:661-4.

5 Sieper J, Braun J. Pathogenesis of spondylarthropathies: persistent bacterial antigen, autoimmunity or both ? Arthritis Rheum 1995;38: 1547-54

6 Gordon FB, Quan AL, Steinman TI, Philip RN. Chlamydia isolates from Reiter's syndrome. Br J Venereal Dis 1973;49:376-9.

7 Inman RD, Chiu B. Synoviocyte-packaged Chlamydia trachomatis induces a chronic aseptic arthritis. J Clin Invest 1998;102:1776-82.

8 Keat A, Thomas B, Dixey J, Osborn M, Sonnex C, Taylor-Robinson D. Chlamydia trachomatis and reactive arthritis: the missing link. Lancet 1987; i:72-4.
9 Keat A Thomas BJ, Taylor-Robinson D. Chlamydial infection in the aetiology of arthritis. Br Med Bull 1983;39:168-74.

10 Norton WL, Lewis D, Ziff M. Light and electron microscopic observations on the synovitis of Reiter's disease. Arthritis Rheum 1966;9:747-57.

11 Schumacher HR, Magge S, Cherian PV, Sleckman J, Rothfuss S, Clayburne $G$, et al. Light and electron microscopic studies on the synovial membrane in Reiter's syndrome: immunocytochemical identification of chlamydial antigen in patients with early disease. Arthritis Rheum 1988;31:937-46

12 Bas S, Griffais R, Kvien TK, Glennas A, Melby K, Vischer TL. Amplification of plasmid and chromosome chlamydia DNA in synovial fluid of patients with arthritis and undifferentiated seronegative oligoarthritis. Arthritis Rheum 1995;38:1005-13.

13 Beatty WL, Morrison RP, Byrne GI. Persistent chlamydiae: from cell culture to a paradigm for chlamydial pathogenesis. Microbiol Rev 1994:58:686-99.

14 Li F, Bulbul R, Schumacher HR Jr, Kieber-Emmons T, Callegari PE, Von Feldt JM, et al. Molecular detection of bacterial DNA in venereal-associated arthritis. Arthritis Rheum 1996;39:950-8.

15 Rahman MU, Cheema MA, Schumacher HR, Hudson AP. Molecular evidence for the presence of Chlamydia in the synovium of patients with Reiter's syndrome. Arthritis Rheum 1992:35:521-9.

16 Taylor-Robinson D, Gilroy CB, Thomas BJ, Keat AC. Detection of Chlamydia trachomatis DNA in joint of reactive arthritis patients by polymerase chain reaction. Lancet 1992;340:81-2.

17 Hammer M, Nettelnbreker E, Hopf S, Schmitz E, Porschke K, Zeidler H. Chlamydial rRNA in the joints of patients with Chlamydia-induced arthritis and undifferentiated arthritis. Clin Exp Rheumatol 1992;10:63-6.

18 Braun J, Tuszewski M, Eggens U, Mertz A, Schaver-Petrowskaja C, Doring $E$, et al. Nested polymerase chain reaction strategy simultaneously targeting DNA sequences of multiple bacterial species in inflammatory joint diseases. I. Screening of synovial fluid samples of patients with spondylarthropathies and other arthritides. J Rheumato 1997;24:1092-100.

19 Braun J, Tuszewski M, Ehlers S, Haberle J, Bollow M, Eggens U, et al. Nested polymerase chain reaction strategy simultaneously targeting DNA sequences of multiple bacterial species in inflammatory joint diseases. II. Examination of sacroiliac and knee joint biopsies of patients with spondylarthropathies and other arthritides. J Rheumatol 1997:24:1101-5

20 Horowitz S, Horowitz J, Taylor-Robinson D, Sukenik S, Apte RN, Bar-David J, et al. Ureaplasma urealyticum in Reiter's syndrome. J Rheumatol 1994;21:877-82

21 Wilkinson NZ, Kingsley GH, Jones HW, Sieper J, Braun J, Ward ME. The detection of DNA from a range of bacterial species in the joints of patients with a variety of arthritides using a nested, broad-range polymerase chain reaction. Rheumatology (Oxford) 1999;38:260-6.

22 Gaston JS, Cox C, Granfors K. Clinical and experimental evidence for persistent Yersinia infection in reactive arthritis. Arthritis Rheum 1999:42:2239-42.

23 Ekman P, Nikkari S, Putto-Laurila A, Toivanen P, Granfors K. Detection of Salmonella infantis in synovial fluid cells in patient with reactive arthritis. J Rheumatol 1999;26:2485-8.

24 Arnold MM, McKenna F. Reactive arthritis in a patient with cat-scratch disease. Postgrad Med J 1997:70:147

25 Aviles RJ, Ramakrishna G, Mohr DN, Michet CJ Jr. Poststreptococcal reactive arthritis in adults: a case series. Mayo Clin Proc 2000;75:144-7

26 Liebling MR, Arkfeld DG, Michelini GA, Nishio M, Eng BJ, Jin T, et al. Identification of Neisseiria gonorrhoeae in synovial fluid using the polymerase chain reaction. Arthritis Rheum 1994;37:702-9.

27 Mattila L, Leirisalo-Repo M, Pelkonen P, Koskimies S, Granfors K, Siitonen A. Reactive arthritis following an outbreak of Salmonella bovismorbificans infection. J Infect 1998;36:289-95.

28 Melby KK, Kvien TK, Glennas A. Helicobacter pylori-a trigger of reactive arthritis? Infection 1999;27:252-5

29 O'Duffy JD, Griffing WL, Li CY, Abdelmalek MF, Persing DH. Whipple's arthritis. Arthritis Rheum 1999;42:812-17

30 Raoult D, Birg ML, La Scola B, Fournier PE, Enea M, Lepidi $H$, et al. Cultivation of the bacillus of Whipple's disease. N Engl J Med 2000;342:620-5.

31 Razavi B. Reactive arthritis after Helicobacter pylori eradication. Lancet 2000;355:720.

32 Veillard E, Guggenbuhl P, Bello S, Lamer F, Chales G. Oligoarthrite réactionnelle au cours d'une colite pseudo-membraneuse à Clostridium difficile. Rev Rhum Engl Ed 1998;65:795-8

33 Wang Q, Vasey FB, Mahfood JP, Valeriano J, Kanik KS, Anderson BE, et al. V2 regions of $16 \mathrm{~S}$ ribosomal RNA used as a molecular marker for the species identification of streptococci in peripheral blood and synovial fluid from patients with psoriatic arthritis. Arthritis Rheum 1999;42:2055-9.

34 Braun J, Laitko S, Treharne J, Eggens U, Wu P, Distler A, et al. Chlamydia pneumoniae: a new causative agent of reactive arthritis and undifferentiated oligoarthritis. Ann Rheum Dis 1994;53:100-5.

35 Hannu T, Puolakkainen M, Leirisalo-Repo M. Chlamydia pneumoniae as a triggering infection in reactive arthritis. Rheumatology (Oxford) 1999;38:411-14.

36 Jaulhac B, Chary-Valckenaere I, Sibilia J, Javier RM, Piemont Y, Kuntz $\mathrm{JL}$, et al. Detection of Borrelia burgdorferi by DNA amplification in synovial tissue samples from patients with Lyme arthritis. Arthritis Rheum 1996;39:736-45. 
37 Nocton JJ, Dressler F, Rutledge BJ, Rys PN, Persing DH, Steere AC Detection of Borrelia burgdorferi DNA by polymerase chain reaction in synovial fluid from patients with Lyme arthritis. N Engl J Med 1994;330:229-34

38 Reiter H. Uber eine bisher unerkannte spirochateninfektion (Spirochaetosis arthritica). Deutsch Med Wochenschrift 1916:42:1535-6.

39 Schaeverbeke T, Lequen L, de Barbeyrac B, Labbe L, Bebear CM, Morrier $Y$, et al. Propionibacterium acnes isolated from synovial tissue and fluid in a patient with oligoarthritis associated with acne and pustulosis. Arthritis Rheum 1998:41:1889-93.

40 Buchs N, Chevrel G, Miossec P. Bacillus Calmette-Guerin induced aseptic arthritis. An experimental model of reactive arthritis. J Rheumatol 1998;25:1662-5.

41 Rosler DH, Citera G, Anaya JM, Cuellar ML, Espinoza LR. Reactive arthritis following Mycobacterium tuberculosis infection in a post-renal transplant patient. Br J Rheumatol 1994:33:692-3.

42 Schaeverbeke T, Sibilia J, Marazanoff V. Molecular detection of BCG therapy for bladder carcinoma [abstract]. Arthritis Rheum 1999;42(suppl):S339.

43 Laasila K, Leirisalo-Repo M. Recurrent reactive arthritis associated with urinary tract infection by Escherichia coli. J Rheumatol 1999:26:2277-9.

44 Tupchong $M$, Simor A, Dewar C. Beaver fever-a rare cause of reactive arthritis. J Rheumatol 1999;26:2701-2.

45 Schumacher HR Jr, Arayssi T, Crane M, Lee J, Gerard H, Hudson AP, et al. Chlamydia trachomatis nucleic acids can be found in the synovium of some asymptomatic subjects. Arthritis Rheum 1999:42:1281-4.

46 Wilbrink B, van der Heiiden IM, Schouls LM, van Embden JD, Hazes JM, Breedveld FC, et al. Detection of bacterial DNA in joint samples from patients with undifferentiated arthritis and reactive arthritis, using polymerase chain reaction with universal 16S ribosomal RNA primers. Arthritis Rheum 1998:41:535-43.

47 Kempsell KE, Cox CJ, Hurle M, Wong A, Wilkie S, Zanders ED, et al. Reverse transcriptase-PCR analysis of bacterial rRNA for detection and characterisation of bacterial species in arthritis synovial tissue. Infect Immun 2000;68:6012-26.

48 Haier J, Nasralla M, Franco AR, Nicolson GL. Detection of mycoplasmal infections in blood of patients with rheumatoid arthritis. Rheumatology (Oxford) 1999;38:504-9.

49 Schaeverbeke T, Gilroy CB, Bebear C, Dehais J, Taylor-Robinson D. Mycoplasma fermentans in joints of patients with rheumatoid arthritis and other rheumatic disorders. Lancet 1996;347:1418.

50 Wilkinson NZ, Kingsley GH, Sieper J, Braun J, Ward ME. Lack of correlation between the detection of Chlamydia trachomatis DNA in synovial fluid from patients with a range of rheumatic diseases and the presence of an antichlamydial immune response. Arthritis Rheum 1998;41:845-54.

51 Schumacher HR Jr, Gerard HC, Arayssi TK, Pando JA, Branigan PJ, Saaibi $D$, et al. Lower prevalence of Chlamydia pneumoniae DNA compared with Chlamydia trachomatis DNA in synovial tissue of arthritis patients. Arthritis Rheum 1999;42:1889-93.

52 Chen T, Luukkainen R, Möttönen T. Failure to detect bacterial DNA in synovial tissue from patients with inflammatory arthritis by using PCR with PAN bacterial 23S rRNA and 16S rRNA primers. Ann Rheum Dis 2000;59(suppl):Pos-113.

53 Gerard HC, Branigan PJ, Schumacher HR Jr, Hudson AP. Synovial Chlamydia trachomatis in patients with reactive arthritis/Reiter's syndrome are viable but show aberrant gene expression. J Rheumato 1998;25:734-42.

54 Koehler L, Dreses-Werringloer U, Gerard H. Induction of a persistent infection of Chlamydia trachomatis by ciproflaxin in vitro [abstract] Arthritis Rheum 1997;40(suppl):S260.

55 Montgomery RR, Malawista SE, Feen KJM, Bockenstedt LK. Direct demonstration of antigenic substitution of Borrelia burgdorferi ex vivo: exploration of the paradox of the early immune response to outer surface proteins $A$ and $C$ in Lyme disease. J Exp Med 1996;183:261-9.

56 Zinkernagel RM. Immunology taught by viruses. Science 1996;271:173-8.

57 Beutler AM, Whittum-Hudson JA, Nanagara R, Schumacher HR, Hudson AP. Intracellular location of inapparently infection Chlamydia in synovial tissue from patients with Reiter's syndrome. Immunol Res 1994; 13:163-71.

58 Branigan PJ, Gerard HC, Hudson AP, Schumacher HR Jr, Pando J. Comparison of synovial tissue and synovial fluid as the source of nucleic acids for detection of Chlamydia trachomatis by polymerase chain reaction. Arthritis Rheum 1996:39:1740-6.

59 Georgilis K, Peacocke M, Klempner MS. Fibroblasts protect the Lyme disease spirochete, Borrelia burgdorferi, from Ceftriaxone in vitro. J Infect Dis 1992; 166:440-4

60 Haupl T, Hahn G, Rittig M, Krause A, Schoerner C, Schonherr U, et al. Persistence of Borrelia burgdorferi in ligamentous tissue from a patient with chronic Lyme borreliosis. Arthritis Rheum 1993;36:1621-6.

61 Preac-Mursic V, Weber K, Pfister HW, Wilske B, Gross B, Baumann A et al. Survival of Borrelia burgdorferi in antibiotically treated patients with Lyme borreliosis. Infection 1998;17:355-7.

62 Priem S, Burmester GR, Kamradt T, Wolbart K, Rittig MG, Krause A. Detection of Borrelia burgdorferi by polymerase chain reaction in synovial membrane, but not in synovial fluid from patients with persisting Lyme arthritis after antibiotic therapy. Ann Rheum Dis 1998;57:1 18-21.

63 Granfors K, Merilahti-Palo R, Luukkainen R, Mottonen T, Lahesmaa R Probst $P$, et al. Persistence of Yersinia antigens in peripheral blood cells from patients with Yersinia enterocolitica O:3 infection with or without reactive arthritis. Arthritis Rheum 1998;41:855-62.
64 Kirveskari J, He Q, Holmstrom T, Leirisalo-Repo M, Wuorela M, Mertsola J, et al. Modulation of peripheral blood mononuclear cell activation status during Salmonella-triggered reactive arthritis. Arthritis Rheum 1999:42:2045-54.

65 Kirveskari J, Jalkanen S, Mäki-lkola $\bigcirc$. Increased synovial endothelium binding and transendothelial migration of mononuclear cells during Salmonella infection. Arthritis Rheum 1998;41:1054-63.

66 Gross DM, Forsthuber T, Tary-Lehmann M, Etling C, Ito K, Nagy ZA, et al. Identification of LFA-1 as a candidate autoantigen in treatment-resistant Lyme arthritis. Science 1998;281:703-6.

67 Lampe MF, Wilson CB, Bevan M, Starnbach MN. Gamma interferon production by cytotoxic $\mathrm{T}$ lymphocytes is required for resolution of Chlamydia trachomatis infection. Infect Immun 1998;66:5457-61.

68 Braun J, Yin Z, Spiller I, Siegert S, Rudwaleit M, Liu L, et al. Low secretion of tumor necrosis factor $\alpha$ but not other Th 1 or Th2 cytokines, by peripheral blood mononuclear cells correlates with chronicity in reactive arthritis. Arthritis Rheum 1999:42:2039-44.

69 Kotake S, Schumacher HR Jr, Arayssi TK, Gerard HC, Branigan PJ, Hudson AP, et al. Gamma interferon and interleukin-10 gene expression in synovial tissues from patients with early stages of Chlamydia-associated arthritis and undifferentiated oligoarthritis and from healthy volunteers. Infect Immun 1999;67:2682-6.

70 Tuokko J, Koskinen S, Westman P, Yli-Kerttula U, Toivanen A, llonen J. Tumour necrosis factor microsatellites in reactive arthritis. Br J Rheumatol 1998;37:1203-6.

71 Yang X, Gartner J, Zhu L, Wang S, Brunham RC. IL-10 gene knockout mice show enhanced Th1-like protective immunity and absent granuloma formation following Chlamydia trachomatis lung infection. J Immunol 1999:162:1010-17.

72 Yin Z, Braun J, Neure L, Wu P, Liu L, Eggens U et al. Crucial role of interleukin-10 interleukin-12 balance in the regulation of the type $2 \mathrm{~T}$ helper cytokine response in reactive arthritis. Arthritis Rheum 1997:40:1788-97.

73 Yin Z, Siegert S, Neure L, Grolms M, Liu L, Eggens U, et al. The elevated ratio of IFN- $\gamma$-/IL-4 positive T cells found in synovial fluid and synovial membrane of rheumatoid arthritis patients can be changed by IL-4 but not by IL-10 or TGF. Rheumatology (Oxford) 1999;38:1058-67.

74 Kaluza W, Leirisalo-Repo M, Marker-Hermann E, Westman P, Reuss E, Hug $R$, et al. IL 10.G microsatellites mark promoter haplotypes associated with protection against the development of reactive arthritis in Finnish patients. Arthritis Rheum 2001;44:1209-14

75 Braun J, Yin Z, Spiller I, Siegert S, Rudwaleit M, Liu L, et al. Low secretion of tumor necrosis factor alpha, but no other Th1 or Th2 cytokines, by peripheral blood mononuclear cells correlates with chronicity in reactive arthritis. Arthritis Rheum 1999;42:2039-44

76 Kapasi K, Inman RD. ME 1 epitope of HLA-B27 confers class I-mediated modulation of gram-negative bacterial invasion. J Immunol 1994; 153:833-40

77 Bas S, Scieux C, Vischer TL. Different humoral immune response to Chlamydia trachomatis major outer membrane protein variable domains I and IV in Chlamydia-infected patients with or without reactive arthritis. Arthritis Rheum 1999:42:942-7.

78 Kuipers JG, Jurgens-Saathoff B, Bialowons A, Wollenhaupt J, Kohler L, Zeidler H. Detection of Chlamydia trachomatis in peripheral blood leukocytes in reactive arthritis by PCR. Arthritis Rheum 1998:41:1894-95.

79 Koehler L, Nettelnbreker E, Hudson AP, Ott N, Gerard HC, Branigan PJ et al. Ultrastructural and molecular analyses of the persistence of Chlamydia trachomatis serovar $\mathrm{K}$ in human peripheral blood monocytes. Microbiol Pathogenesis 1997;22:133-42.

80 Nanagara R, Li F, Beutler A, Hudson A, Schumacher HR Jr. Alteration of Chlamydia trachomatis biologic behaviour in synovial membranes. Arthritis Rheum 1995:38:1410-17.

81 Rook GAW, Stanford JL. Slow bacterial infections or autoimmunity? mmunol Today 1992;12:160-4.

82 Granfors K, Jalkanen S, Lindberg AA, Maki-lkola O, von Essen R, Lahesmaa-Rantala $R$, et al. Salmonella liposaccharide in synovial cells from patients with reactive arthritis. Lancet 1990;335:685-8.

83 Granfors K, Jalkanen S, von Essen R, Lahesmaa-Rantala R, Isomaki O Pekkola-Heino K, et al. Yersinia antigens in synovial fluid cells from patients with reactive arthritis. N Engl J Med 1989:320:216-21.

84 Hammer M, Zeidler H, Klimsa S, Heesemann J. Yersinia enterocolitica in the synovial membrane in patients with Yersinia-induced arthritis. Arthritis Rheum 1990;33:1795-800.

85 Huppertz HI, Heesemann J. Experimental Yersinia infection of human synovial cells: persistence of live bacteria and generation of bacterial antigen deposits including ghosts, nucleic acid-free bacterial nods. Infect Immun 1996:64:1484-7.

86 Merilahti-Palo R, Pelliniemi L, Granfors K, Soderstrom KO, von Essen $R$, Simila $A$, et al. Electron microscopy and immunolabeling of Yersinia antigens in human synovial fluid cells. Clin Exp Rheumato 1994:12:255-9.

87 Salmi M, Jalkanen S. Human leukocyte subpopulations from inflamed gut bind to joint vasculature using distinct sets of adhesion molecules. J Immunol 2001;166:4650-7.

88 Ringrose JH. HLA B27 associated spondylarthropathy, an autoimmune disease based on crossreactivity between bacteria and HLA-B27? Ann Rheum Dis 1999;58:598-610. 
89 Schulze-Koops H, Burkhardt H, Heesemann J, von der Mark K, Emmrich $F$. Characterization of the binding region for the Yersinia enterocolitica adhesin YadA on types I and II collagen. Arthritis Rheum 1995;38:1283-9.

90 Jaulhac B, Heller R, Limbach FX, Hansmann Y, Lipsker D, Monteil H, et al. Direct molecular typing of Borrelia burgdorferi sensu lato species in synovial samples from patients with lyme arthritis. J Clin Microbiol 2000;38: 1895-900.

91 Taurog JD, Richardson JA, Croft JT, Simmons WA, Zhou M, Fernandez-Sueiro JL, et al. The germfree state prevents development of gut and joint inflammatory disease in HLA-B27 transgenic rats. J Exp Med 1994; 180:2359-64.

92 Sobao Y, Tsuchiya N, Takiguchi M, Tokunaga K. Overlapping peptide-binding specificities of HLA-B27 and B39. Arthritis Rheum 1999:42:175-81.

93 Kapasi K, Inman RD. HLA B27 expression modulates gram-negative bacterial invasion into transfected L cells. J Immunol 1992;148:3554-9

94 Laitio P, Virtala M, Salmi M, Pelliniemi L, Yu DT, Granfors K. HLA B27 modulates intracellular survival of Salmonella enteritidis in human monocytic cells. Eur J Immunol 1997:27:1331-8.

95 Virtala M, Kirveskari J, Granfors K. HLA B27 modulates the survival of Salmonella enteritidis in transfected $L$ cells, possibly by impaired nitric oxide production. Infect Immun 1997;65:4236-42.

96 Mear JP, Schreiber KL, Munz C, Zhu X, Stevanovic S, Rammensee HG, et al. Misfolding of HLA-B27 as a result of its B pocket suggests a novel mechanism for its role in susceptibility to spondyloarthropathies. J Immunol 1999; 163:6665-70.

97 Colbert RA. HLA-B27 misfolding: a solution to the spondyloarthropathy conundrum? Mol Med Today 2000;6:224-30.

98 Toivanen $\mathbf{P}$, Toivanen A. Two forms of reactive arthritis? Ann Rheum Dis 1999;58:737-41.

99 Di Genaro MS, Munoz E, Aguilera C, de Guzman AM. Yersinia enterocolitica $0: 8$ and $0: 5$ lipopolysaccharide arthritogenicity in hamsters. Rheumatology (Oxford) 2000;39:73-8.
100 Zhang X, Rimpilainen M, Simelyte E, Toivanen P. What determine arthritigenicity of bacterial cell wall? A study on Eubacterium cell wall-induced arthritis. Rheumatology (Oxford) 2000;39:274-82.

101 Mertz AK, Ugrinovic S, Lauster R, Wu P, Grolms M, Bottcher U, et al. Characterization of the synovial $T$ cell response to various recombinant Yersinia antigens in Yersinia enterocolitica-triggered reactive arthritis: heat-shock protein 60 drives a major immune response. Arthritis Rheum 1998;41:315-26.

102 Ugrinovic S, Mertz A, Wu P, Braun J, Sieper J. A single nonamer from the Yersinia $60-\mathrm{kDa}$ heat shock protein is the target of HLA-B27-restricted CTL response in Yersinia-induced reactive arthritis. J Immunol 1997; 159:5715-23.

103 Deng GM, Nilsson IM, Verdrengh M, Collins LV, Tarkowski A. Intra-articulary localized bacterial DNA containing CpG motifs induces arthritis. Nat Med 1999;5:702-5.

104 Deng GM, Tarkowski A. The features of arthritis induced by CpG motifs in bacterial DNA. Arthritis Rheum 2000;43:356-64.

105 Yi AK, Tuetken R, Redford T, Waldschmidt M, Kirsch J, Krieg AM. CpG motifs in bacterial DNA activate leukocytes through the $\mathrm{pH}$-dependent generation of reactive oxygen species. J Immunol 1998;160:4755-61.

106 Kuipers JG, Nietfeld L, Dreses-Werringloer U, Koehler L, Wollenhaupt J, Zeidler $\mathrm{H}$, et al. Optimised sample preparation of synovial fluid for detection of Chlamydia trachomatis DNA by polymerase chain reaction. Ann Rheum Dis 1999;58:103-8.

107 Van der Heiiden IM, Wilbrink B, Vije AE, Schouls LM, Breedveld FC Tak PP. Detection of bacterial DNA in serial synovial samples obtained during antibiotic treatment from patients with septic arthritis. Arthritis Rheum 1999:42:2198-203.

108 Nikkari S, Möttönen T, Saario R, Yli-Kerttula U, Leirisalo-Repo M, Laitio $P$, et al. Demonstration of Salmonella DNA in the synovial fluid in reactive arthritis [abstract]. Arthritis Rheum 1996;39 (suppl 9):S185. 